\title{
Winter Bird Use of Urban and Rural Habitats in Ontario
}

\author{
PAUL G. R. SMITH \\ Resource Management Branch, Ministry of Agriculture and Food, 1 Stone Road West, 3rd Floor South, Guelph, Ontario \\ N1G 4Y2 Canada
}

Smith, Paul G. R. 2003. Winter bird use of urban and rural habitats in Ontario. Canadian Field-Naturalist 117(2): 173-183.

This study examined variation in winter bird diversity, abundance, biomass and species and guild composition on plots in farmland, rural forests, mixed rural habitat, cities and three categories of urban natural areas in southern Ontario. Small $(<20 \mathrm{~g})$, insectivorous, upper canopy, bark foraging and forest species were more prevalent in rural mixed habitat, urban natural areas and especially rural forests. Larger (20-100 g), ground feeding and omnivorous birds typified cities and farms. Many bird species classified as forest, forest edge and field species during summer also favored these same habitats during winter. The 52 sample plots can be accurately classified into the seven habitat categories through discriminant analysis using the percentages of small species, insectivores, forest species and alien species. Urban natural areas, forests and mixed rural habitat showed the highest diversity while cities and farms showed the lowest diversity. Both bird abundance and biomass were highest in urban natural areas with open water and urban residential and commercial areas, whereas both were lowest in farmland.

Key Words: bird populations, urban ecology, winter, urban-rural ecological gradient, Ontario.

The landscapes of Ontario south of the Canadian Shield, like much of eastern North America, are mosaics of cities, farms, forests and successional habitats. The effects of urbanization, farming and fragmentation on breeding birds have been widely studied. This is less true of wintering birds (Erskine 1980; 1992; Hohtola 1978; Lancaster and Rees 1979; Blake 1987; Tilghman 1987; Telleria and Santos 1995; Morneau et al. 1996). Understanding the effects of landscape change on birds depends on knowledge of effects of habitat on birds during all seasons. This paper compares and contrasts winter bird use of seven urban and rural habitat categories in terms of avian diversity, abundance, biomass, bird size, guilds and species composition.

Urban ecosystems generally have lower biological diversity compared to forests and rural habitats (Gilbert 1989; Adams 1994; Marzluff et al. 1998). However, along with the lower diversity, urban bird assemblages often show greater abundance and biomass than do those in forests (Erskine 1980; Hohtola 1978; Lancaster and Rees 1979; Adams 1994).

Farmland is a mosaic of habitats for birds, but many farmland birds are edge species associated with hedgerows and remnant natural vegetation, and other typically urban species may be associated with farm buildings (Rodenhouse et al. 1995). Relatively few species are specifically associated with croplands (Møller 1984). Nevertheless, some croplands provide considerable food in soil invertebrates and seed (Lack 1992). Areas with more diversity in farm habitats and in farming practices show far greater diversity of bird life (Parrish et al. 1994; Bignal and McCraken 1996; Newton 1998).

The effect on bird life of habitat fragmentation from farming and urbanization is now a central issue in conservation biology (Whitcomb et al. 1981; Ambuel and Temple 1983; Robbins et al. 1989; Saunders et al. 1991; Hinsley et al. 1996; Nour et al. 1999). The affinities of breeding species for field, forest edge and forest habitats are now well established. A few studies suggest that similar affinities exist for wintering bird species (Blake 1987; Tilghman 1987; Telleria and Santos 1995).

Winter and breeding bird assemblages differ in many respects. In temperate regions, bird species-richness and abundance are lower during winter, due to the absence of neotropical and short-distance migrants (Morrison et al. 1987). Snow cover and depth limit ground foraging (Erskine 1980). Winter is a critical time for many resident species, and winter events can affect population levels during the breeding season (e.g., Mehlman 1997). Patterns of species presence have changed not only due to habitat modifications, but also due to increases in bird feeders in urban and rural areas (Root 1988; Wilson 1994).

Periodic "eruptions" of northern seed-eating and raptorial species in particular years during winter can dramatically increase local densities of birds and change species composition (Bock and Lepthien 1976; Root 1988; Hochachka et al. 1999). Intra-species and inter-species flocking is important in winter bird assemblages. This phenomenon relates to the reduced sedentary and territorial behavior during winter and is thought to have adaptive significance (e.g., Berner and Grubb 1985; Morrison et al. 1987).

While many aspects of breeding bird use of different urban and rural habitat categories have been thoroughly studied, research on winter birds is sketchy. Therefore, this research addressed the following specific questions. Are the well-documented differences in diversity, abundance, biomass and species composition among rural and urban breeding bird communities similar for 
wintering birds in southern Ontario? How does the more limited range of food types during winter affect the guilds and sizes of birds using different habitat categories? Are the now familiar preferences of breeding bird species for forest, forest edge and field evident in winter habitat use? To address these questions, this study analyzed differences in winter bird use of different habitat categories in rural and urban areas in southern Ontario, Canada. It examined variation in winter bird diversity, abundance, biomass and species and guild composition on plots in farmland, forests, mixed rural habitat, cities and three categories of urban natural areas.

\section{Methods}

\section{Study Plots}

The Winter Bird Population Study (WBPS) is a method for sampling the winter birds of defined census plots (Kolb 1965; Robbins 1972, 1981). Eight to ten, and occasionally fewer, counts on each fixed-area plot are conducted in December through February. The WBPS method can be robust to the use of different observers on different plots (Smith 1984a).

Fifty-two plots from across southern Ontario were used in this study (Appendix), drawn from those published in American Birds and Ontario Field Biologist. Further description of some plots can be found elsewhere (Campbell and Dagg 1976; Erskine 1975; Smith et al. 1981, 1982; Smith 1984a, b). Climate varies across the geographic range of locations of these study plots and influences the distribution and abundance of a number of species (Erskine 1980). Climate and other factors contribute to the large year-to-year variation in the winter occurrence and abundance of many species (Bock and Lepthien 1976; Bock and Root 1981; Root 1988; Smith 1984a).

\section{Habitat Classification}

The study plots reflect different habitat categories in urban and rural southern Ontario and were classified into seven categories - three rural and urban categories (cf., Brady et al. 1979). These reflect gradients of human modification through urbanization and agriculture. Table 1 summarizes the classification of habitat categories. This classification has significant limitations but provides a basis for assessing some broad scale patterns.

Fourteen of the plots are drawn from a range of rural landscapes including rural forest, mixed rural habitats and farmland.

Seven rural forested plots included deciduous, mixed and coniferous forests (1-7, in Appendix). Six of the plots were within larger continuous protected habitats including conservation lands, Rondeau Provincial Park and St. Lawrence Islands National Park.

Four plots were composed of mixed rural habitats including forest, old field (successional), and agricultural field (8-11, in Appendix).
Three plots composed of farmland were included (50-52 in the Appendix).

Thirty-three plots reflect a range of urban habitat categories including urban and suburban residential, commercial and urban natural areas including parks, urban open space, woodlands and other natural or semi-natural areas within cities and towns. These plots reflect different levels of disturbance along an urbanization gradient.

Twenty-seven plots of urban natural areas included ravines, valleys, woodlots, and parks. Urban natural areas were divided into three categories as described in Table 1. Five plots in urban natural areas with more than $50 \mathrm{~m}^{2}$ open water during the winter were classified as a separate category, urban natural with water (12-16 in Appendix). The presence of open water is known to significantly influence abundance, diversity and species composition of winter bird assemblages (Tilghman 1987; Gilbert 1989; Adams 1994). The other 22 plots in urban natural areas were divided into those more or less than 10 ha in area (Table 1). Twelve plots were $>10$ ha (17-28 in Appendix), while a further ten were $<10$ ha (29-38 in Appendix). This division reflects the fact that area is known to significantly influence the diversity and species composition of winter bird assemblages (Blake 1987; Tilghman 1987; Telleria and Santos 1995). Exploratory data analysis of these 27 plots indicated that area and presence of open water were important variables in explaining variance among the 27 plots and therefore a useful means to categorize the urban natural areas.

Urban areas or "cities" included two downtown plots, four plots in older, high-density residential parts of three cities, and one plot in a small town (39-49 in the Appendix). Four other plots were located in suburban, lower-density portions of two cities.

\section{Variables Selected for Analysis}

A variety of measures of avian community structure and composition were used to examine variation across the habitat categories. Winter bird diversity, abundance, biomass, mass, guild structure and species composition were all examined.

Ecological and avian diversity have been measured in a wide variety of ways to address different definitions of diversity and methodological issues (Magurran 1988). Consequently, several indices of diversity were employed in this study. The number of species recorded was the measure of species richness. Species richness is known to have inherent and sampling-based biases (Hill 1973; James and Rathbun 1982; Magurran 1988) and so other indices of diversity were used. Simpson's diversity index, $\mathrm{N}_{2}\left(\mathrm{~N}_{2}=1 / \Sigma \mathrm{p}_{\mathrm{i}}\right.$, where $\mathrm{p}_{\mathrm{i}}$ is the proportion of each species), a common measure of diversity (Hill 1973), was also used. Plot area was used as a covariate in analyzing species richness and Simpson's diversity index $\left[\mathrm{N}_{2}\right]$ to correct for the known correlation of diversity with plot area (James and Rathbun 1982; Magurran 1988). 
TABLE 1. A description of the habitat categories used in this study.

\begin{tabular}{|c|c|c|}
\hline $\begin{array}{l}\text { Urban / } \\
\text { Rural }\end{array}$ & $\begin{array}{l}\text { Habitat } \\
\text { Category }\end{array}$ & Description \\
\hline Rural Areas & Forest & $\begin{array}{l}\text { Naturally occurring deciduous, coniferous or mixed forest in a rural landscape } \\
\text { consisting primarily of natural habitats and farmland. }\end{array}$ \\
\hline Rural Areas & Mixed Rural & $\begin{array}{l}\text { Plots that include more than one of farmland, successional field, } \\
\text { wetland and forest in a rural landscape consisting primarily of natural } \\
\text { habitats and farmland. }\end{array}$ \\
\hline Rural Areas & Farm & $\begin{array}{l}\text { Lands used for crops or pasture with little significant natural vegetation except } \\
\text { hedgerows, occurring in a rural landscape consisting of farmland and natural } \\
\text { habitats. No farm buildings were present on these plots. }\end{array}$ \\
\hline Urban Areas & $\begin{array}{l}\text { Urban } \\
\text { Natural }\end{array}$ & $\begin{array}{l}\text { Public open spaces with a mixture of natural habitats and horticultural } \\
\text { vegetation, surrounded by residential, commercial or industrial areas and } \\
\text { located within cities with }>50,000 \text { people. Sites in this category were }>10 \text { ha } \\
\text { in extent. The WPBS plot generally occupied the full extent of the natural } \\
\text { area or park. }\end{array}$ \\
\hline Urban Areas & $\begin{array}{l}\text { Urban Natural } \\
\text { with Open Water }\end{array}$ & $\begin{array}{l}\text { As for Urban Natural, with open water at least } 50 \mathrm{~m}^{2} \text { in extent on a creek, } \\
\text { river or pond. }\end{array}$ \\
\hline Urban Areas & $\begin{array}{l}\text { Small Urban } \\
\text { Natural }\end{array}$ & As for Urban Natural, but $\leq 10$ ha in extent. \\
\hline Urban Areas & City & $\begin{array}{l}\text { Commercial or residential areas within cities or small towns and dominated by } \\
\text { buildings and pavement. The sites vary in the density of buildings, the } \\
\text { percentage of area covered by pavement and the amount of horticultural } \\
\text { vegetation present. Both higher-density urban core areas and lower-density } \\
\text { suburban areas are included. }\end{array}$ \\
\hline
\end{tabular}

Rarefaction is a technique for comparing collections of items with unbalanced sample sizes, which has always been a problem in measuring ecological diversity (Engstrom and James 1981; James and Rathbun 1982; Brewer and Williamson 1994; Gotelli and Colwell 2001). In this study, the expected number of species in a sample of five birds $\left[\mathrm{E}\left(\mathrm{S}_{5}\right)\right]$ was used as the rarefaction index of diversity (James and Rathbun 1982).

Total bird abundance, total land bird abundance and the abundance of each species were assessed as the number of birds per hectare, consistent with standard methods for the Winter Bird Population Study (Kolb 1965; Robbins 1972, 1981). For total abundance, the number of survey hours per hectare was used as a covariate to correct for sampling effort (similar to the suggestion of Bock and Root 1981).

Biomass and average bird size or mass for each plot were calculated in a manner similar to Mauer (1985) using the average mass values for bird species compiled by Dunning (1993). The average mass for each species was multiplied by the average number of birds of that species found on the plot. Total biomass was summed across all species and divided by the plot area in hectares. Similarly, average bird mass was calculated as the total biomass divided by the total number of birds.

The occurrence of birds in different size classes was examined by determining for each plot the percent- age of birds in four size classes: $<20 \mathrm{~g} ; 20-40 \mathrm{~g} ; 40-$ $100 \mathrm{~g}$; and $>100 \mathrm{~g}$.

The percentages of birds in different feeding and substrate guilds were estimated using the guild classifications of DeGraaf et al. (1985). Note that a species may be classified in more than one guild. The percentage of field, forest edge and forest species was calculated based on the species' affinities noted by Cadman et al. (1987), Whitcomb et al. (1981), Root (1988), and Freemark and Collins (1992). These are classifications based on breeding season preferences. In this paper I test the applicability of such classifications to winter bird habitat analyses.

\section{Statistical Methods}

Analysis of variance was used to test for significant differences in bird community variables among habitat categories. For sites with more than one year of sampling, the mean values for each plot were used to avoid the problem of pseudoreplication (Hulburt 1984). Where departures from the normal distribution and homogeneity of variances could not be overcome through transformation, the non-parametric KruskalWallis analysis of variance test was applied.

\section{Results}

Diversity

Bird species richness, Simpson's diversity index $\left(\mathrm{N}_{2}\right)$ and the rarefaction diversity index $\left[\mathrm{E}\left(\mathrm{S}_{5}\right)\right]$ all differed significantly $(\mathrm{P}<0.0001, \mathrm{P}<0.01$ and $\mathrm{P}<0.001$ 
respectively) among the habitat categories (Table 2). Urban natural areas, forests and mixed habitats showed the highest avian diversity while city and farm showed the lowest diversity (Table 2). Larger urban natural areas (> 10 ha) had diversity indices $5-19 \%$ higher than forests.

City areas supported half as many species and about $70 \%$ the levels of Simpson's diversity index, $\mathrm{N}_{2}$, as forests. The rarefaction diversity index $\left[\mathrm{E}\left(\mathrm{S}_{5}\right)\right]$ in city areas was about $75 \%$ of that for forests. Farmland diversity levels were about one-third those for forests, except the rarefaction diversity index $\left[\mathrm{E}\left(\mathrm{S}_{5}\right)\right]$ which was $69 \%$ the value for forests. Species richness in mixed rural habitats was about $20 \%$ lower than in rural forests, whereas other indices were about as high or higher than values in forests (Table 2).

\section{Abundance, Biomass and Size}

Total bird abundance (Table 2) was significantly different $(\mathrm{P}<0.01)$ among the habitat categories, due to particularly high abundances in two habitat categories. Total bird abundance was highest in urban natural areas with open water and residential and commercial city areas. Farmland and rural mixed habitats had the lowest levels. Forests and urban natural areas had similar, intermediate levels of bird abundance.

Total bird biomass was significantly different among habitat categories $(\mathrm{P}<0.001)$. The highest values were recorded in urban natural areas with open water, due to the presence of waterfowl, and in city areas, due to higher densities and larger species such as the Rock Dove (Columba livia). Other urban natural areas and forest had intermediate biomass levels (Table 2).

In urban natural areas with open water, total abundance was $80 \%$ higher than in rural forests. Total biomass was 13 times greater in urban natural areas with open water than in rural forests (Table 2). Other urban natural areas showed bird abundance and biomass levels similar to rural forests. Both farms and mixed rural habitats showed abundance levels roughly one third of rural forests. Biomass on farmland was about $30 \%$ that in forests while biomass in mixed rural habitats was about $60 \%$ of that in forests. Mean bird size was roughly $40 \%$ higher in farmland compared with forests. Total bird abundance in cities was $46 \%$ higher than that recorded in forests. Biomass was $90-100 \%$ higher in cities than in forests.

Significant differences $(\mathrm{P}<0.001)$ among habitat categories in the occurrence of birds of different sizes (Figure 1) indicate the cause of the trends of differences in overall biomass shown in Table 2. A preponderance of small bird species $(<20 \mathrm{~g})$ is indicative of forested habitats, as is a relatively even mix of the other size classes. Mixed rural habitats differed from forests primarily in having additional birds in the $>100 \mathrm{~g}$ class, specifically more raptors. In fact, rural mixed habitats had the highest average bird size. In contrast, city areas showed a preponderance of birds in the intermediate 20-40 gram and 40-100 gram ranges.

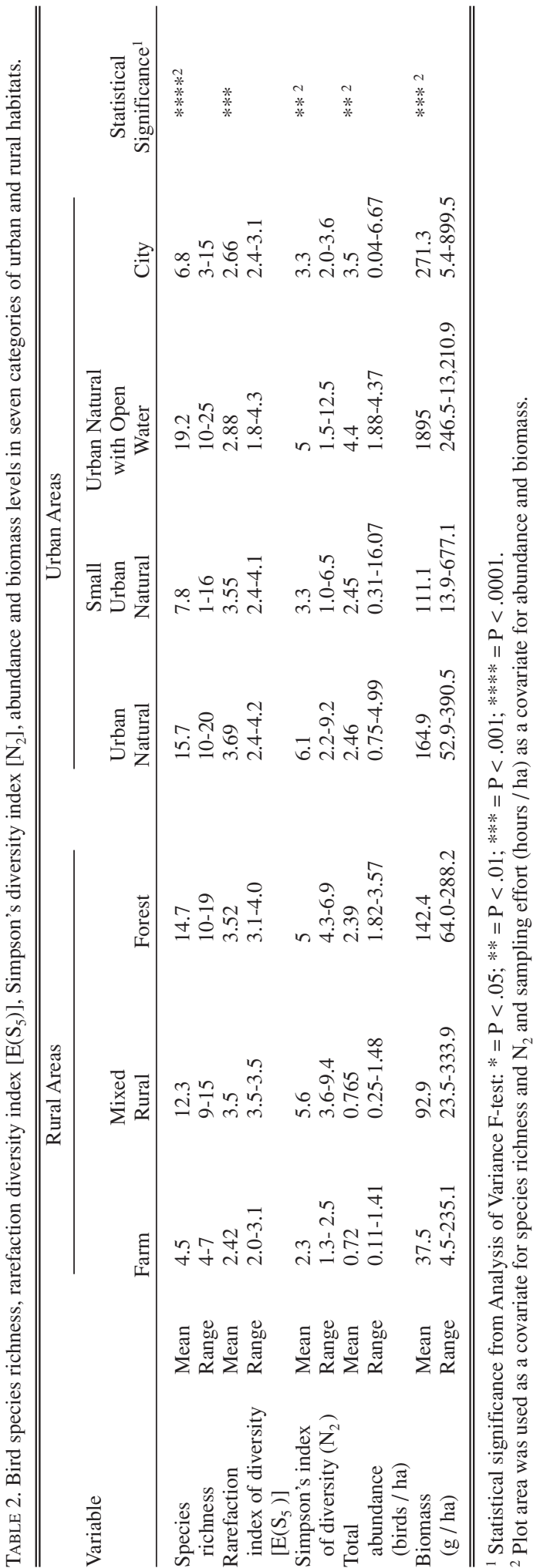


The latter category includes the House Sparrow (Passer domesticus) and Starling (Sturnus vulgaris). Farm areas had a predominance of birds in the 40-100 gram range, which includes the Snow Bunting (Plectrophenax nivalis) and Eastern Meadowlark (Sturnella magna) (Figure 1).

\section{Guilds}

Of food-based feeding guilds, the percentage of insectivorous birds differed most (statistically significance $\mathrm{P}<0.0001$ ) among habitats (Table 3 ). Forests, with 25.3 percent, had the highest percentage of insectivores, followed by farms (19.1 percent) and mixed rural habitats (16.7 percent). Cities had only 1.5 percent insectivorous birds. This pattern shows small insectivorous bird species were more indicative of natural, rural forest conditions. Rural mixed habitat shows the highest proportion of carnivorous birds. No significant differences were found among habitat categories for the percentages of omnivores, granivores, herbivores or frugivores (Table 3 ).

The percentage of four substrate-based guilds differed significantly $(\mathrm{P}<0.01)$ among habitat categories (Table 3). Ground-gleaning and foraging species predominated in all urban and farm habitats. Lower canopy species were also important in urban natural areas and rural mixed habitats. In forests, a more even distribution is evident with significant proportions of birds that forage in the upper and lower canopy, on tree trunks and on the ground.

\section{Species Composition}

Species showing significant differences $(\mathrm{P}<0.05)$ in abundance among the seven habitat categories are shown in Table 4. Of the fifteen most common species only Pine Siskin (Carduelis pinus), Evening Grosbeak (Coccothraustes vespertinus), and Cedar Waxwing (Bombycilla cedrorum) failed to show significant differences among habitat categories, all species subject to periodic extreme peaks in winter abundance (Bock and Lepthien 1976; Root 1988).
Predictably the three alien species - House Sparrow, European Starling and Rock Dove-occurred almost exclusively in city and urban natural areas (Table 4). Some other species reached their greatest abundances in urban natural areas (Table 4), including Mourning Dove (Zenaida macroura), American Robin (Turdus migratorius), and Northern Cardinal (Cardinalis cardinalis).

Species associated with forest edge and fields are the most common in this study. The species American Robin through White-breasted Nuthatch (Sitta carolinensis) in Table 4 are generally regarded as either field or forest-edge species. The proportion of forestedge species is fairly constant at roughly half of birds in forest, mixed rural and urban natural area habitats.

Brown Creeper (Certhia americana), Goldencrowned Kinglet (Regulus satrapa), Red-breasted Nuthatch (Sitta canadensis), Ruffed Grouse (Bonasa umbellus), and Hairy Woodpecker (Picoides villosus) showed the clearest affinities for forest habitats (Table 4). Fourteen other species generally regarded as forest species during the breeding season occurred at frequencies too low to reveal statistical trends. One third of winter birds recorded in forest areas are regarded as forest species, a much higher percentage than for all other habitats $(\mathrm{P}<0.001)$. This analysis suggests that a suite of bird species can be identified that preferentially use forest during winter, as well as during the breeding season.

\section{Differences Among Habitat Categories}

A series of significant ecological gradients is revealed in the percentages of small birds, insectivorous species, forest species and alien species across the seven habitat categories in urban and rural southern Ontario. These four variables can be used to summarize the differences in avifauna of the seven habitat categories using multivariate analysis (Table 5). The percentages of birds $<20 \mathrm{~g}$ in mass, of insectivorous species, of alien species and of forest species separate

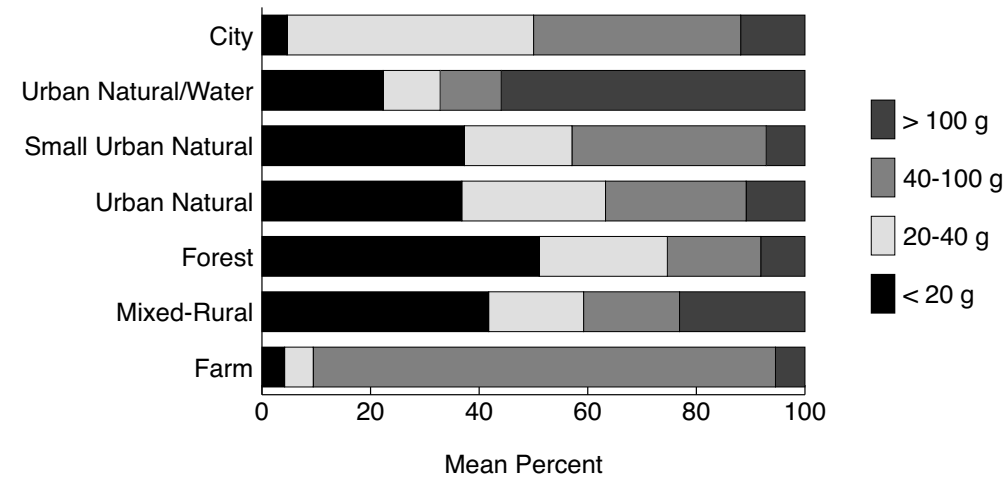

FIGURE. 1. The distribution of birds in four size classes in seven categories of urban and rural habitats. Analysis of variance showed highly significant differences $(\mathrm{P} \leq 0.001)$. 


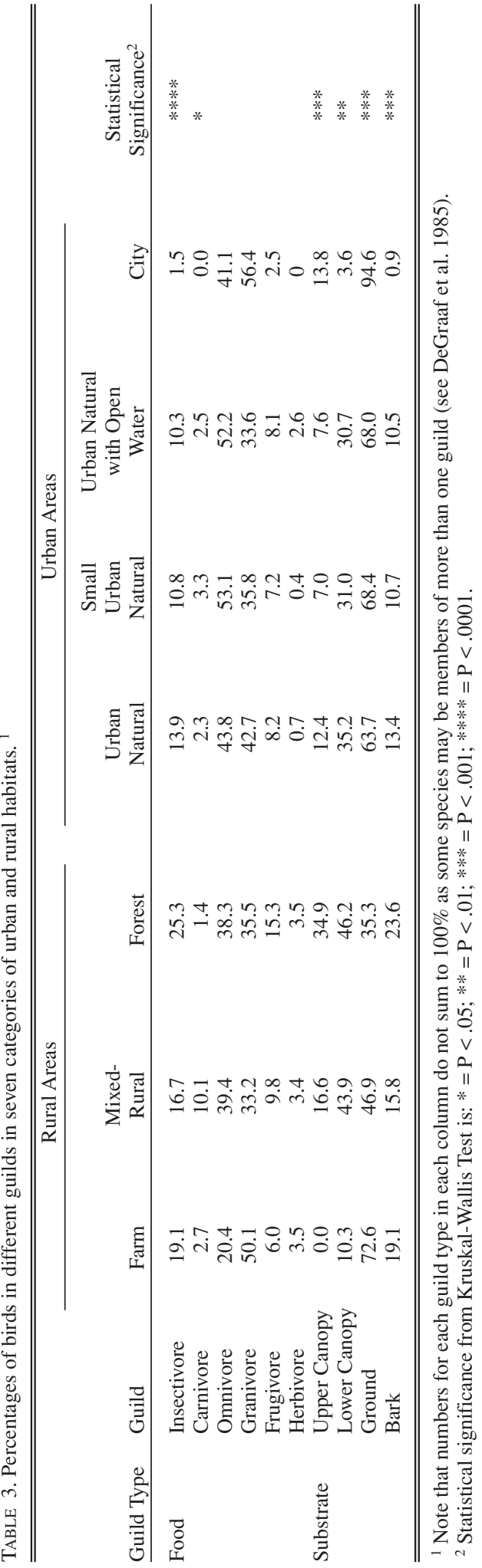

the seven habitat categories in a non-parametric, Epanechnikov kernel discriminant analysis (Hand 1982). The technique successfully categorized 96.2 percent of the 52 plots $(\mathrm{P}<0.0001)$. Only two plots were mis-categorized and these were two urban natural area plots classified in one of the other two categories of urban natural areas.

\section{Discussion}

Patterns revealed here regarding winter bird species richness and diversity in urban and rural habitats were similar to other studies in different climatic zones (Lancaster and Rees 1979; DeGraaf and Wentworth 1981, 1986; Tilghman 1987; Adams 1994). Diversity was higher in forest, rural mixed habitats and urban natural areas compared with cities and farms. Tilghman (1987) found species richness in an urban area in Massachusetts, U.S. was only $50 \%$ of that in forests and a similar finding is reported here, in a colder region with more consistent snow cover.

In northern and temperate ecosystems, bird species richness and abundance are lower in winter than summer (Anderson et al. 1981; Morrison et al. 1987). The magnitude of the seasonal difference in avian diversity and abundance also differs among habitats. Some studies show that in winter, birds favor areas with greater vegetation cover compared to summer (Morrison et al. 1987, western U.S.) and areas with milder microclimates (Shields and Grubb 1976, north central U.S.). Urban areas provide larger, more stable food supplies, higher temperatures and reduced temperature variability which may result in higher avian productivity and survival rates (Marzluff et al. 1998).

Total bird abundance and biomass were highly variable and differences among habitat categories did not explain much of the variance. The presence of water and riparian bird species had a major influence on total avian abundance in this study. Waterfowl are known to move into cities in the winter due to the higher temperatures and resulting open water (Tilghman 1987; Gilbert 1989; Adams 1994). The occasional occurrence of flocks of northern finches has been noted as a possible cause of low explanatory power of habitat variables related to bird abundance (Tilghman 1987). Intra-species and inter-species flocking, known to be important in winter bird assemblages (e.g., Berner and Grubb 1985; Morrison et al. 1987), might also contribute to greater variability. Abundance is also affected by landscape effects at larger scales than individual study plots (Pearson 1993; Hostletler and Holling 2000).

The differences in the sizes of birds present in different habitat categories are remarkable and this has not been examined to any extent in North America. Hostletler and Holling (2000) found that birds of different sizes responded to the amount of urban forest cover at different scales. In this study, smaller birds $(<20 \mathrm{~g})$ favored forests, mixed rural habitats and 


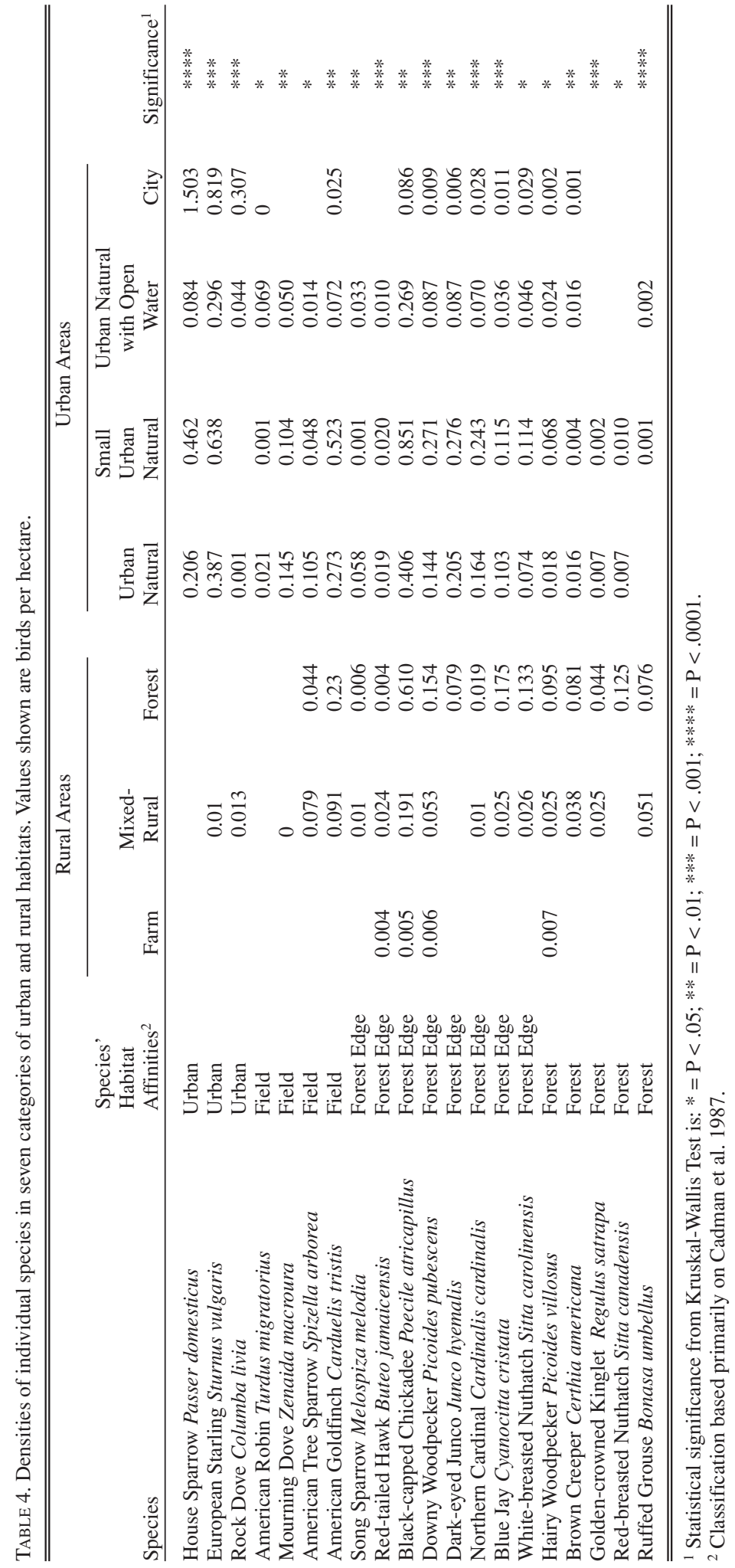




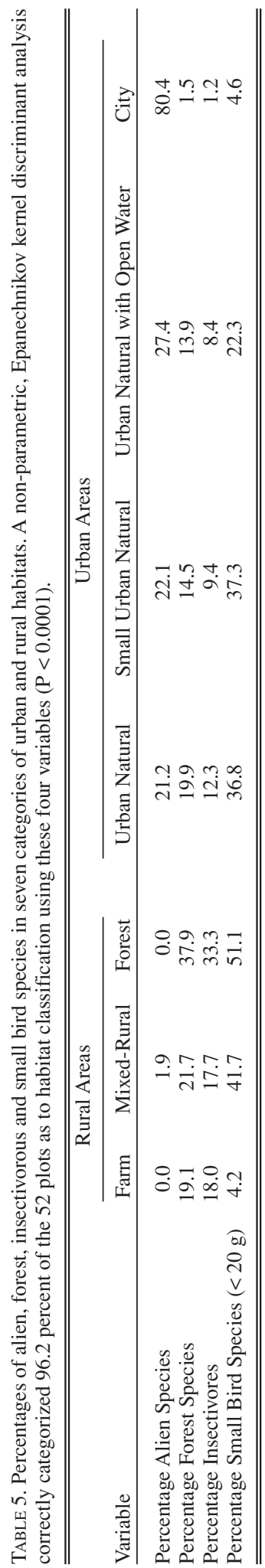

urban natural areas. Larger birds, 20-100 g in size, were prevalent in cities and on farms. Marzluff et al. (1998) speculated that urbanization likely favours ground foraging bird species and discourages canopy and bark foragers. Ground-foraging birds characteristic of open country are generally larger than species foraging on branches in woodland habitats (e.g., Polo and Carrascal 1999). More complex forested habitats are thought to provide greater opportunities for small birds foraging among branches and milder microclimates, especially protection from wind. Woodlands may support a larger variety of sizes of wintering bird species as observed in this study.

Both cities and farms favor a small number of granivorous and omnivorous species (Møller 1984; O'Connor and Shrubb 1986; Lack 1992; Adams 1994; Marzluff et al. 1998). The volume of food available to birds in some cities is enormous, perhaps more than the entire bird assemblage would require (Lancaster and Rees 1979). Raptor populations are sometimes lower in cities (Tomialojc 1982; Adams 1994) and this study suggests this may be the case in southern Ontario. In this study, granivorous and omnivorous birds were ubiquitous in all habitats, consistent with the available winter food. Significant variation in the proportion of insectivores across the habitat categories was a major trend noted in this study and one variable that best distinguishes the seven habitat categories.

The identification of species' preferences during summer for field, forest edge and forest has been widespread (Whitcomb et al. 1981; Ambuel and Temple 1983; Robbins et al. 1989; Freemark and Collins 1992). But investigation of species' preferences during winter has been more limited (Blake 1987; Tilghman 1987; Telleria and Santos 1995). This study corroborates preliminary work in the northern United States on species' preferences during winter (Blake 1987, Illinois; Tilghman 1987, Massachusetts) and suggests a broader trend across several climatic zones. Many of the species associated with forest, forest edge and field during summer show similar preferences during winter.

Some interesting new findings arise from analysis of winter bird use of urban and rural habitats in southern Ontario, as well as corroboration and extension of results from a few other studies of winter bird use in the northern U.S. (Blake 1987; Tilghman 1987). Small, insectivorous and forest species were prevalent in forests while larger, ground feeding and omnivorous birds overwhelmingly dominated cities and farms. Urban natural areas occupy an intermediate point on this gradient from natural rural forests to most humanmodified sites on farms and in cities. Granivorous and omnivorous species dominated all habitat categories. Variation in the abundance of small, insectivorous, upper and lower canopy and forest bird species was one of the major sources of variance in this study. Trends in biomass and bird sizes suggest further research on these aspects of winter bird communities. 
The different habitat categories can be successfully classified based on the percentages of small species, insectivores, forest species and alien species using multivariate discriminant analysis. More research on winter bird use of farmland habitats in North America would be useful given the patterns found in European work. Additional work measuring species preferences in winter for forest, forest-edge and field habitats would also be useful given the interesting results so far.

\section{Acknowledgments}

Thanks are extended to the volunteers who conducted the winter bird population studies used in this paper. The Toronto Bird Observatory, James L. Baillie Fund and Toronto Field Naturalists, supported many of these field studies. John Theberge provided support and guidance at early stages of this research. Mike Cadman, Paul Eagles, Anthony Erskine, George Francis, John Theberge and anonymous reviewers provided comments on drafts of the manuscript.

\section{Literature Cited}

Adams, L. 1994. Urban wildlife habitats: a landscape perspective. University of Minneapolis Press, Minneapolis.

Ambuel, B., and S. Temple. 1983. Area-dependent changes in the bird communities and vegetation of southern Wisconsin forests. Ecology 64: 1057-1068.

Anderson, B., R. Ohmart, and J. Rice. 1981. Seasonal changes in avian densities and diversities. Pages 262-264 in Estimating the Numbers of Terrestrial Birds. Edited by C. Ralph and J. Scott. Studies in Avian Biology 6.

Berner, T., and T. Grubb. 1985. An experimental analysis of mixed-species flocking in birds in deciduous woodland. Ecology 66: 1229-1236.

Bignal, E., and D. McCraken. 1996. Low-intensity farming systems in the conservation of the countryside. Journal of Applied Ecology 33: 413-424.

Blake, J. 1987. Species-area relationships of winter residents in isolated woodlots. Wilson Bulletin 99: 243-250.

Bock, C., and L. Lepthien. 1976. Synchronous eruptions of boreal seed-eating birds. American Naturalist 110: 559571.

Bock, C., and T. Root. 1981. The Christmas Bird Count and avian ecology. Pages 17-23 in Estimating the Numbers of Terrestrial Birds. Edited by C. Ralph and J. Scott. Studies in Avian Biology 6.

Brady, R., T. Tobias, P. Eagles, R. Ohrner, J. Micak, B. Weale, and R. Dorney. 1979. A typology for the urban ecosystem and its relationship to larger biogeographical landscape units. Urban Ecology 4: 11-28.

Brewer, A., and M. Williamson. 1994. A new relationship for rarefaction. Biodiversity and Conservation 3: 373-379.

Cadman, M., P. Eagles, and F. Helleiner. 1987. Atlas of the breeding birds of Ontario. University of Waterloo Press, Waterloo, Canada.

Campbell, C., and A. Dagg. 1976. Bird populations in downtown and suburban Kitchener-Waterloo, Ontario. Ontario Field Biologist 30: 1-22.

DeGraaf, R., and J. Wentworth. 1981. Urban bird communities and habitats in New England. Transactions of the North American Wildlife and Natural Resources Conference 46: 396-413.
DeGraaf, R., and J. Wentworth. 1986. Avian guild structure and habitat associations in suburban bird communities. Urban Ecology 9: 399-412.

Degraaf, R., N. Tilghman, and S. Anderson. 1985. Foraging guilds of North American birds. Environmental Management 9: 493-536.

Dunning, J. 1993. The CRC handbook of avian body masses. CRC Press, Boca Raton, Florida.

Engstrom, R., and F. James. 1981. Plot size as a factor in winter-bird population studies. Condor 83: 34-41.

Erskine, A. 1992. A ten-year urban winter bird count in Sackville, New Brunswick. Canadian Field-Naturalist 106: 499-506.

Erskine, A. 1980. Urban birds in the context of Canadian climate and settlement. Pages 1321-1326 in Symposium on Urbanization. Edited by R. Murton and M. Luniak. Proceedings of the $17^{\text {th }}$ International Ornithological Congress. Berlin, Germany.

Erskine, A. 1975. Winter birds of urban residential areas in eastern Canada. Pages 18-31 in Nature and Urban Man. Edited by G. McKeating. Canadian Nature Federation, Special Publication Number 4.

Freemark, K., and B. Collins. 1992. Landscape ecology of birds breeding in temperate forest fragments. Pages 443454 in Ecology and management of Neotropical Migrant Landbirds. Edited by J. Hagan and D. Johnson. Smithsonian Press, Washington.

Gilbert, O. 1989. The ecology of urban habitats. Chapman and Hall, London.

Gotelli, N., and R. Colwell. 2001. Quantifying biodiversity: procedures and pitfalls in the measurement and comparison of species richness. Ecology Letters 4: 379-391.

Hand, D. 1982. Kernel discriminant analysis. Research Studies Press, New York.

Hill, M. 1973. Diversity and evenness: a unifying notation and its consequences. Ecology 54: 427-432.

Hinsley, S., P. Bellamy, I. Newton, and T. Sparks. 1996. Influences of population size and woodland area on bird species distributions in small woods. Oecologia 105: 100-107.

Hochachka, W., J. Wells, K. Rosenberg, D. TessagliaHymes, and A. Dhondt. 1999. Irruptive migration of common redpolls. Condor 101: 195-204.

Hohtola, E. 1978. Differential changes in bird community structure with urbanization: a study in central Finland. Ornis Scandinavica 9: 94-100.

Hostletler, M., and C. Holling. 2000. Detecting the scales at which birds respond to structure in urban landscapes. Urban Ecosystems 4: 25-54.

Hulburt, S. 1984. Pseudoreplication and the design of ecological experiments. Ecological Monographs 54: 187-211.

James, F., and S. Rathbun. 1982. Rarefaction, relative abundance, and diversity of avian communities. Auk 98: 785-800.

Kolb, H. 1965. The Audubon winter bird population study. Audubon Field Notes 19: 432-434.

Lack, P. 1992. Birds on lowland farms. HMSO, London.

Lancaster, R., and W. Rees. 1979. Bird communities and the structure of urban habitats. Canadian Journal of Zoology 57: 2358-2368.

Magurran, A. 1988. Ecological diversity and its measurement. Princeton University Press, Princeton, New Jersey.

Marzluff, J., F. Gehlbach, and D. Manuwal. 1998. Urban environments: influences and challenges for the avian conservationist. Pages 283-299 in Avian Conservation: 
Research and Management. Edited by J. Marzluff and R. Sallabanks. Island Press, Washington, D.C.

Mauer, B. 1985. Avian community dynamics in desert grasslands: observational scale and hierarchical structure. Ecological Monographs 55: 295-312.

Mehlman, D. 1997. Change in avian abundance across the geographic range in response to environmental change. Ecological Applications 7: 614-624.

Møller, A. 1984. Community structure of birds in agricultural areas in summer and winter in Denmark. Holarctic Ecology 7: 413-418.

Morneau, F., M. St-Georges, D. Lambert, et J.-L DesGranges. 1996. Assemblages d'oiseaux en hiver dans des parc urbains de 39 villes des basses-terres du St. Laurent : richesse, habitat et comparaison biogéographique. G.R.E.B.E. inc. pour Environnement Canada. Série de rapports techniques (258). Service canadien de la faune, Région du Québec.

Morrison, M., K. With, I. Timossi, and K. Milne. 1987. Composition and temporal variation of flocks in the Sierra Nevada. Condor 89: 739-745.

Newton, I. 1998. Bird conservation problems resulting from agricultural intensification in Europe. Pages 307-322 in Avian Conservation: Research and Management. Edited by J. Marzluff and R. Sallabanks. Island Press, Washington, D.C.

Nour, N., R. Van Damme, E. Matthysen, and A. Dhondt. 1999. Forest birds in forest fragments: are fragmentation effects independent of season? Bird Study 46: 279-288.

O'Connor, R., and M. Shrubb. 1986. Farming and birds. Cambridge University Press, Cambridge, U.K.

Parrish, T., K. Lakhani, and T. Sparks. 1994. Modelling the relationship between bird population variables and hedgerow and other field margin attributes. I. Species richness of winter, summer and breeding birds. Journal of Applied Ecology 31: 764-775.

Pearson, S. 1993. The spatial extent and relative influence of landscape level factors on wintering bird populations. Landscape Ecology 8: 3-18.

Polo, V., and L. Carrascal. 1999. Shaping the body size distribution of passeriformes: habitat use and body size are evolutionarily and ecologically related. Journal of Animal Ecology 68: 324-337.

Robbins, C. 1972. An appraisal of the winter bird population study technique. American Birds 26: 688-692.

Robbins, C. 1981. Reappraisal of the Winter Bird Population Study technique. Pages 52-57 in Estimating the Numbers of Terrestrial Birds. Edited by C. J. Ralph and J. M. Scott. Studies in Avian Biology 6.
Robbins, C., D. Dawson, and B. Dowell. 1989. Habitat area requirements of breeding forest birds of the middle Atlantic states. Wildlife Monographs (103).

Rodenhouse, N., L. Best, J. O'Connor, and E. Bollinger. 1995. Effects of agricultural practices and farmland structures. Pages 269-293 in Ecology and Management of Neotropical Migratory Birds, A Synthesis and Review of Critical Issues. Edited by T. Martin and D. Finch. Oxford University Press, Oxford, United Kingdom.

Root, T. 1988. Atlas of wintering birds of North America: an analysis of Christmas bird count data. University of Chicago Press, Chicago.

Saunders, D., R. Hobbs, and C. Margules. 1991. Biological consequences of ecosystem fragmentation: a review. Conservation Biology 5: 18-32.

Shields, W., and T. Grubb. 1976. Winter bird densities on north and south slopes. Wilson Bulletin 86: 125-130.

Smith, P. 1984a. Observer and annual variation in winter bird population studies. Wilson Bulletin 96: 561-574.

Smith, P. 1984b. Winter birds of small urban woodlots in Kitchener-Waterloo. American Birds 38: 60-61.

Smith, P., G. Fairfield, D. Burton, and D. Knauber. 1982. Winter bird communities of urban southern Ontario. American Birds 36: 46-47.

Smith, P., D. Knauber, D. Ulster, D. Banville, J. MacDonald, G. Fairfield, and D. Burton. 1981. Winter bird communities of selected areas in Toronto. American Birds 35 :41-44.

Telleria, J., and T. Santos. 1995. Effects of forest fragmentation on a guild of wintering passerines: the role of habitat selection. Biological Conservation 71: 61-67.

Tilghman, N. 1987. Characteristics of urban woodlands affecting winter bird diversity and abundance. Forest Ecology and Management 21: 163-175.

Tomialojc, L. 1982. Synurbization of birds and the preypredator relations. Pages 131-140 in Animals in Urban Environment. Edited by M. Luniak and B. Pisarski, Polish Academy of Sciences, Warsaw.

Whitcomb, R., C. Robbins, J. Lynch, B. Whitcomb, M. Klimkiewicz, and D. Bystrak. 1981. Effects of forest fragmentation on avifauna of the eastern deciduous forest. Pages 125-205 in Forest Island dynamics in man-dominated landscapes. Edited by R. Burgess and D. Sharpe. Springer Verlag, New York.

Wilson, W. 1994. The distribution of wintering birds in central Maine: the interactive effects of landscape and bird feeders. Journal of Field Ornithology 65: 512-519.

Received 14 December 2000

Accepted 29 October 2003 
APPENDIX. The 52 Winter Bird Population Study plots in southern Ontario used in this paper.

\begin{tabular}{|c|c|c|c|c|c|c|c|}
\hline $\begin{array}{l}\text { Site } \\
\#\end{array}$ & $\begin{array}{l}\text { Site } \\
\text { Name }\end{array}$ & $\begin{array}{l}\text { Region } \\
\text { County/ }\end{array}$ & $\begin{array}{r}\text { Area } \\
\text { (ha) }\end{array}$ & $\begin{array}{l}\text { Site } \\
\#\end{array}$ & $\begin{array}{l}\text { Site } \\
\text { Name }\end{array}$ & $\begin{array}{l}\text { Region } \\
\text { County/ }\end{array}$ & $\begin{array}{r}\text { Area } \\
\text { (ha) }\end{array}$ \\
\hline 1 & Chats Falls & Ottawa-Carleton & 8.4 & 25 & Nordheimer Ravine & Toronto & 10.1 \\
\hline 2 & Purpleville A & York & 17.4 & 26 & Wigmore Ravine & Toronto & 34.0 \\
\hline 3 & Chesney Bog & Oxford & 15.2 & 27 & Sherwood Park & Toronto & 18.5 \\
\hline \multirow[t]{2}{*}{4} & St. Lawrence Island & & & 28 & Waterloo Park A & Waterloo & 24.3 \\
\hline & National Park & Leeds & 12.5 & 29 & Blockline/ Strasbourg & Waterloo & 1.2 \\
\hline 5 & Purpleville B & York & 10.5 & 30 & Campus Woodlot & Waterloo & 0.8 \\
\hline 6 & Rondeau Provincial Park & Kent & 6.1 & 31 & Salt Spring Road & Waterloo & 0.7 \\
\hline \multirow[t]{2}{*}{7} & South Walsingham & Haldimand- & & 32 & Upper Gerrard Ravine & Toronto & 5.0 \\
\hline & & Norfolk & 10.1 & 33 & Old Country Road & Waterloo & 0.7 \\
\hline \multirow[t]{2}{*}{8} & Flamboro area & Hamilton- & & 34 & Village Woods & Waterloo & 0.7 \\
\hline & & Wentworth & 41.7 & 35 & Hidden Valley & Waterloo & 1.2 \\
\hline 9 & Homer Watson & Waterloo & 10.1 & 36 & Chatsworth Ravine & Toronto & 4.4 \\
\hline \multirow[t]{2}{*}{10} & Dundas area & Hamilton- & & 37 & Mabel Davis & York & 6.5 \\
\hline & & Wentworth & 6.3 & 38 & Rockway Gardens & Waterloo & 2.3 \\
\hline 11 & Acton area & Halton & 4.9 & 39 & Downtown Waterloo & Waterloo & 25.0 \\
\hline 12 & Victoria Park & Waterloo & 22.9 & 40 & Downtown Ottawa & Ottawa-Carleton & 41.0 \\
\hline 13 & Waterloo Park B & Waterloo & 24.3 & 41 & Westboro/ Highland & Ottawa-Carleton & 111.0 \\
\hline 14 & Bayview Woods & Toronto & 20.0 & 42 & Kent/Percy & Ottawa-Carleton & 50.6 \\
\hline \multirow[t]{2}{*}{15} & Cootes Paradise & Hamilton- & & 43 & Hemlock/ Hickory & Waterloo & 25.0 \\
\hline & & Wentworth & 13.0 & 44 & Guelph & Wellington & 4.0 \\
\hline 16 & Riverside Park & Waterloo & 81.0 & 45 & Carleton Place & Ottawa-Carleton & 103.0 \\
\hline 17 & Steckle Woods & Waterloo & 26.2 & 46 & Alta Vista & Ottawa-Carleton & 97.1 \\
\hline 18 & Moore Park & Toronto & 13.2 & 47 & Copeland/Belair & Ottawa-Carleton & 111.0 \\
\hline 19 & Strathgowan Woods & Toronto & 8.1 & 48 & Rockcliffe Park & Ottawa-Carleton & 87.0 \\
\hline 20 & Cedarvale Ravine & Toronto & 20.0 & 49 & Beechwood & Waterloo & 25.0 \\
\hline 21 & Rosedale Valley & Toronto & 19.4 & 50 & Vaughan A & York & 20.2 \\
\hline 22 & Park Drive & Toronto & 19.6 & 51 & Carp River & Ottawa-Carleton & 70.8 \\
\hline 23 & Lakeside Park & Waterloo & 14.2 & 52 & Vaughan B & York & 40.5 \\
\hline 24 & Humber River - Land & Toronto & 10.9 & & & & \\
\hline
\end{tabular}

